\title{
FEMINISME : ANTARA OTORITER DAN OTORITATIF
}

\author{
Endrizal \\ Jurusan Sosiologi Agama FUAD LAIN Bukittinggi \\ E-mail: rizalpiliang84@gmail.com
}

\begin{tabular}{|c|c|c|}
\hline Diterima: 1 Agustus 2018 & Direvisi: 23 November 2018 & Diterbitkan: 31 Desember 2018 \\
\hline
\end{tabular}

\begin{abstract}
This paper is a philosophical description of women's knowledge. Does gender affect the way and what knowledge will be obtained by someone. If we follow the thesis of historical materialism of Marxism, then the answer is "yes, "because a person's position in the relations of production determines the way he knows, and what content he will acquire, and women, in patriarchal society, the disadvantaged position. Then, whether to provide a critical assessment of the way and content of gender-affected knowledge requires a certain universal rationality assessment criterion. If so, how to make that rationality no longer a new force of oppressors, as claimed by postmodern thinkers. Feminism, as a philosophical movement and reflection, must use certain universal rationality and criteria of judgment without falling on totalitarianism on the one hand, or relativism on the other. Feminism must be authoritative without being authoritarian.
\end{abstract}

Keyword: Feminisme, otoritative, otoritare

\begin{abstract}
Abstrak
Makalah ini adalah deskripsi filosofis dari pengetahuan perempuan. Apakah gender memengaruhi cara dan pengetahuan apa yang akan diperoleh seseorang. Jika kita mengikuti tesis materialisme historis Marxisme, maka jawabannya adalah "ya," karena posisi seseorang dalam hubungan produksi menentukan cara dia tahu, dan konten apa yang akan dia peroleh, dan wanita, dalam masyarakat patriarki, yang kurang beruntung posisi. Kemudian, apakah akan memberikan penilaian kritis tentang cara dan isi pengetahuan yang terpengaruh gender memerlukan kriteria penilaian rasionalitas universal tertentu. Jika demikian, bagaimana menjadikan rasionalitas itu bukan lagi kekuatan penindas baru, seperti yang diklaim oleh para pemikir postmodern. Feminisme, sebagai gerakan dan refleksi filosofis, harus menggunakan rasionalitas universal tertentu dan kriteria penilaian tanpa jatuh pada totalitarianisme di satu sisi, atau relativisme di sisi lain. Feminisme harus berwibawa tanpa menjadi otoriter.
\end{abstract}

Kata kunci: Feminisme, otoritatif, otoritare

\section{Pendahuluan}

Pengetahuan tidak hanya pengetahuan. Pengetahuan selalu dibentuk oleh situasi politik dan relasi-relasi kekuasaan yang mempengaruhi "sang subyek pengetahuan" tersebut. Di dalam sejarah filsafat, ada beberapa pemikir yang memiliki kerangka berpikir relativistik semacam itu. Beberapa di antara mereka adalah pemikir feminis. Mereka menantang pendapat yang menyatakan bahwa "pengetahuan adalah pengetahuan", dan kemudian mencari kurangnya atau lebihnya dari definisi tersebut, yang menyatakan bahwa ternyata pengetahuan tidak hanya (pengetahuan).

Para filsuf, yang berpendapat bahwa kebenaran hanyalah merupakan "pujian kosong" (Rorty, 1980: 10), tentu akan melihat bahwa pengetahuan kurang dapat menggambarkan apa sesungguhnya yang dapat digambarkan, sehingga mereka skeptis terhadap obyektivitas epistemologis dan ontologis dari pengetahuan manusia. Akan tetapi, secara politis, argumentasi tersebut juga dapat bersikap kritis terhadap relasi-relasi kekuasaan di dalam masyarakat, yang mungkin 
saja diuntungkan (dan pasti merugikan yang lain), jika suatu kebenaran atau pengetahuan tertentu dilestarikan. Dan karena perempuan selalu menempati posisi yang 'kurang kuat' di dalam relasi-relasi kekuasaan, maka wajarlah para pemikir feminis mencoba menemukan pola-pola yang menindas di dalam pendefinisian pengetahuan manusia, yang biasanya kerap menjadikan perempuan sebagai 'korban'. Para pemikir epistemologi feminis ingin 'menelanjangi' bias gender di dalam pengetahuan manusia, dan membuka selubung relasi-relasi kekuasaan institusionalisasi pengetahuan tersebut di dalam masyarakat (Lennon dan Margaret, 1994: 63).

Tesis seperti itu tidak tanpa kritik. Ada beberapa filsuf lain, di antara mereka ada beberapa pemikir feminis, yang berpendapat bahwa posisi relativistik semacam itu tidaklah terlalu meyakinkan. Akan tetapi, walaupun mereka menolak paradigma relativistik, mereka tetap tidak setuju dengan tesis yang menyatakan bahwa pengetahuan adalah pengetahuan, lepas dari perbedaan gender. Gender merupakan salah satu faktor yang menentukan kemampuan manusia mengetahui, dan apa yang nanti akan dipahaminya.

Feminisme memiliki teori titik pijak yang jelas pada pemikiran Marx tentang materialisme historis (Rorty, 1989: 73-74). Tesis utama dari pemikiran Marx yang sangat mempengaruhi analisis feminisme adalah, bahwa kelompok sosial yang berbeda memiliki titik tolak epistemik yang juga berbeda. Dalam hal ini, posisi di dalam relasi-relasi produksi mempengaruhi bentuk pengetahuan yang dimiliki seseorang. Proletariat dapat memahami peran mereka sebagai subyek revolusioner, karena mereka memiliki posisi di dalam jaring-jaring relasi produksi yang tepat, yakni sebagai kelompok yang tertindas. Hal yang sama terjadi pada perempuan yang hidup di dalam masyarakat patriarkal, di mana mereka seringkali menderita ketidakadilan, baik itu politik, ekonomi, maupun sosial.

Tesis kedua adalah bahwa identitas sosial akan sangat berpengaruh di dalam proses mencapai pengetahuan akan sesuatu, yakni proses menyatakan pendapat, menyangkal, meminta sesuatu, memberikan argumentasi, dan sebagainya. Hal inilah mungkin yang disebut Bourdieu sebagai habitus. Proses subyek mengetahui sesuatu sudah selalu bersifat timbal balik antara subyek tersebut dengan obyek yang ingin diketahuinya. Dan jika gender, kelas sosial, ataupun etnis tertentu mempengaruhi latar belakang subyek yang mengetahui, maka identitas sosial subyek dan kekuasaan yang ada di belakangnya tidak hanya persoalan sosiologi pengetahuan semata, tetapi lebih mendasar lagi, yakni persoalan epistemologis.

Dari latar belakang ini, keterlibatan feminisme di dalam epistemologi mengambil setidaknya dua bentuk. Pertama, feminisme akan mengambil alih perspektif postmodernisme, yang seringkali bersifat anti fondasionalisme dan anti epistemology (Lennon dan Margaret, 1994: 63). Kedua, feminisme akan menggunakan paradigma epistemologis yang lebih peka, baik secara politis maupun secara sosiologis atas relasirelasi kekuasaan yang berlangsung di masyarakat. Mayoritas pemikir feminis mengambil alih perspektif yang kedua. Akan tetapi, pendekatan postmodernisme, yang juga sangat peka pada semua bentuk universalisasi dan absolutisasi, juga berpengaruh besar terhadap refleksi para pemikir feminis.

\section{Pendekatan Postmodern}

Feminisme postmodern menggantikan pandangan yang utuh dan satu tentang perempuan dan identitas gender feminin dengan konsepsi yang plural dan kompleks tentang identitas sosial, menempatkan gender sebagai salah satu faktor penentu di antara faktor-faktor lainnya, seperti kelas sosial, 
etnisitas, suku, usia, dan orientasi seksual (Nicholson, 1990: 34-35). Dari sudut pandang ini, feminisme postmodern dianggap telah memberikan suatu landasan konseptual yang menyatakan, bahwa identitas sosial individu itu terfragmentasi dan beragam. Tesis ini memang dekat dengan perspektif para pemikir postmodern (Nicholson,1990: 234-236). Akan tetapi, tesis tentang fragmentasi identitas sosial manusia tidak selalu diidentikan dengan perspektif postmodernisme.

Dengan kata lain, postmodernisme tidak memiliki hak untuk memonopoli tesis yang menyatakan bahwa identitas sosial individu adalah sesuatu yang kompleks dan terfragmentatif. Memang, postmodernisme berupaya menangkap semua fenomena lokal dan partikular dalam keberlainannya, serta menunda asumsi yang bersifat universal. Perspektif ini mau menangkap gejala lokal obyek sedekat mungkin tanpa terpengaruh bias-bias universalisme. Kita tentunya memiliki alasan untuk berpendapat bahwa ontologi sosial adalah ontologi yang terfragmentatif, terutama jika pendapat tersebut dapat menangkap gejala obyek ataupun fenomena secara lebih detil dan akurat daripada universalisme, yang cenderung mengkategorikan lokalitas pada kelas sosial tertentu, sehingga pada akhirnya mereduksi.

Pemikir postmodern mengadopsi tesis ontologi sosial yang terfragmentatif bukan untuk mencapai keakuratan analisis, melainkan atas dasar motivasi politis, yang berpendapat bahwa setiap ontologi totalitas adalah cara berpikir yang eksklusif dan totaliter. Motivasi tersebut bukan tanpa pendasaran epistemologis. Dalam kaca mata pemikir postmodern, setiap kategori umum dan universal selalu dianggap tidak mampu menangkap keberagaman identitas dan posisi sosial yang dialami oleh 'manusia-manusia real'. Identitas adalah sesuatu yang parsial, strategis, dan seringkali kontradiktif (Benhabib, 1995: 27). Di dalam kerangka feminisme postmodern, pengenalan dan pengakuan akan perbedaan adalah sebentuk kewajiban politis untuk menciptakan iklim keterbukaan dan inklusifitas daripada meraih keakuratan analisis, yang lebih bersifat epistemologis.

Ada beberapa hal, yang kiranya dapat menjadi kritik bagi posisi politik postmodernisme. Penolakan akan perbedaan seringkali dimampatkan pada konsep eksklusif, yang berarti ada pihak-pihak ataupun kelompok tertentu yang berada di luar pertimbangan-pertimbangan politik, karena mereka berbeda, baik secara kelas sosial, gender, ataupun suku. Akan tetapi, konsep eksklusif pada dirinya sendiri tidaklah mampu menjerat maksud penindasan secara tepat. Perjuangan para feminis lebih dari sekedar tuntutan untuk diikutsertakan, yakni perjuangan untuk mencapai perubahan. Tujuan telah sering dirumuskan ulang dan tetaplah benar sampai sekarang, bahwa politik feminis akan memperjuangkan lebih dari sekedar keinginan untuk diikutsertakan; feminis akan berjuang untuk mencapai perubahan (Lovibond, 1989: 12).

Kepedulian para pemikir feminis dengan penerimaan perbedaan didorong oleh suatu komitmen politik untuk merumuskan suatu teori kritis yang memadai, yang kemudian mampu menginspirasikan suatu gerakan politik. Sementara, para pemikir postmodern merumuskan tesis ontologi sosial yang terfragmentatif lebih untuk memperjuangkan penerimaan akan lokalitas, partikularitas, yang notabene memiliki languange games-nya masingmasing. Pada titik ini, pertanyaan demikian akan muncul, apakah postmodernisme akan membantu feminisme untuk memperoleh landasan epistemologis yang memadai dalam merumuskan suatu pemikiran kritis?

Tesis-tesis utama postmodernisme dapat ditemukan dalam karya Lyotard, yang berjudul The Postmodern Condition. Buku tersebut adalah salah satu karya pemikir postmodern 
yang paling orisinal dan berpengaruh. Pada buku tersebut, kita akan menemukan komitmen yang definitif untuk menentang segala bentuk epistemologi totalitas, dan perjuangan untuk tetap mempertahankan 'languange games' yang bersifat lokal. Tidak ada norma-norma yang bersifat trans-lokal. Tidak ada justifikasi dan rasionalitas yang berlaku untuk semua 'languange games'. Setiap upaya untuk merumuskan jenis rasionalitas ataupun justifikasi semacam itu dianggap sebagai tindakan teror. "Setiap peraturan", demikian Lyotard, "yang mendefinisikan suatu permainan dan gerak yang dapat dimainkan di dalamnya haruslah lokal. Dengan kata lain, disetujui oleh pemain yang terlibat dan dapat dibatalkan pada akhirnya nanti..."(Lyotard, 1984: 66).

Tesis Lyotard tentang lokalitas disini bukanlah melulu berarti lokalitas kebudayaan, ataupun lokalitas dari suatu kelompok sosial, melainkan lebih pada lokalitas dari suatu 'languange games'. Languange games tersebut hanya disepakati oleh pihak-pihak yang terkait. Dari titik ini, kita bisa menarik kesimpulan bahwa intensi dasar postmodernisme untuk berperang melawan totalitas (Lyotard, 1984: 82) dapat dikategorikan sebagai suatu bentuk relativisme. Languange games mengacu pada sesuatu yang mengambang dan dibentuk secara sukarela, yakni sebagai sesuatu yang lebih dekat didefinisikan sebagai percakapan individual yang singular, daripada sebagai praktek diskursif yang stabil di dalam sejarah. Tentu saja, para pemikir postmodern memaknai languange games tersebut dengan cara yang berbeda-beda. Akan tetapi, tulisan Lyotard dapat menjadi model untuk menjelaskan tendensi anti epistemologi di dalam postmodernisme, yang nantinya juga akan mendapat banyak kritik.

Lubang besar di dalam paradigma politik postmodernisme sebenarnya dapat ditarik kembali pada fondasi epistemologis pemikiran mereka, yakni penekanan pada lokalitas.
Penekanan pada lokalitas tidak dapat merumuskan suatu bentuk pemikiran kritis, seperti penilaian pada sistem suatu organisasi sosial yang tidak adil, ataupun suatu kepercayaan yang dianggap benar ternyata salah, karena mereka mengklaim lokalitas mereka. Dengan kata lain, postmodernisme, alih-alih membebaskan manusia, justru dapat sebaliknya menindas manusia atas nama lokalitas dan perbedaan, sehingga sikap kritis dari luar suatu languange games tertentu tidak lagi diperbolehkan.

Jika kita menentang penindasan yang ada dengan mengacu pada akal sehat dan rasionalitas yang kritis, maka kita akan dituduh sebagai "penjajah" yang berpikir secara totaliter dan otoriter. Pada level estetika, postmodernisme memang dapat mendorong terciptanya kreativitas. Akan tetapi, hal ini tidaklah menutupi fakta, bahwa di level pemikiran kritis, postmodernisme menggantikan rasionalitas dengan pemujaan pada krisis dan chaos yang pesimistis. "Postmodernisme", demikian tulis Fricker, "menggantikan rasionalitas progresif yang dinamis dengan sikap kritis pesimistis yang menyedihkan (Rorty, 1980: 65).

Feminisme postmodern dapat pula mengambil strategi yang sama melawan semua bentuk universalisasi norma, dan kemudian sungguh-sungguh berpihak pada lokalitas. Mereka mungkin akan mengambil alih tesis Lyotard tentang otonomi languange games yang bersifat lokal. Akan tetapi, apakah penggunaan tesis postmodern untuk kepentingan perjuangan feminisme itu dapat mengembangkan penilaian kritis? Misalnya, ketika ada teriakan-teriakan perjuangan, seperti bayaran yang sama untuk kerja yang sama, atau perbudakan itu salah. Kedua teriakan perjuangan tersebut mengandaikan adanya nilai-nilai universal yang dilanggar, yakni nilainilai kemanusiaan, yang memperlakukan manusia secara setara, apapun statusnya. Postmodern bukanlah tipe paradigma yang 
tepat dihadapan klaim-klaim tersebut, karena penguasa dapat bilang bahwa mereka memiliki nilai-nilai kemanusiaanya sendiri, language games-nya sendiri, yang bersifat lokal, dan mereka menerapkannya dalam situasi politik. Dengan demikian, penguasa memiliki languange games-nya sendiri, yang tidak dapat dinilai dengan menggunakan nilai-nilai yang bersifat universal. Penilaian semacam itu, dari kaca mata postmodernisme, ada sebuah cara berpikir yang totaliter.

Postmodernisme tidak akan mampu memperjuangkan suatu nilai-nilai emansipatoris hanya dengan berpijak pada lokalitas, tanpa berupaya untuk menguniversalisasi suatu bentuk nilai tertentu. Situasi ini, adalah sebuah penurunan, yakni untuk beranggapan norma-norma yang telah diberikan oleh kebudayaan, masyarakat, dan tradisi akan mencukupi untuk membuat seseorang bersikap kritis untuk mewujudkan masa depan yang diinginkan (Benhabib, 1995: 27). Apakah kita mau menyarankan bahwa proyek modernitas sudah selesai, dan bahwa cita-cita untuk menciptakan masyarakat yang lebih rasional dan egaliter sudah lewat serta ketinggalan jaman?. Bagaimana seseorang bisa berkata pada saya untuk mengucapkan selamat tinggal kepada "metanarasi emansipatoris", ketika emansipasi saya masihlah jauh, dan dianggap sebagai sesuatu yang bukan apaapa(Lovibond, 1989: 12).

Pendapat Benhabib dan Lovibond tersebut tentu akan ditanggapi sinis oleh para pemikir postmodern. Bagi mereka, setiap metanarasi adalah sebentuk terorisme, yang mau menciptakan suatu hukum umum tentang dunia. Dalam konteks ini sebenarnya ada dua pihak. Di satu sisi, ada pihak yang berkuasa, yang mau menciptakan semacam hukum umum versi mereka. Di sisi lain, ada pihak yang tertindas, yang juga memiliki semacam hukum umum versi mereka sendiri. Hanya, dalam konteks pihak yang tertindas, tidak ada yang mendengarkan mereka, karena mereka berada pada pihak yang lemah. Problemnya, jika para pemikir postmodern menuduh setiap pihak yang merumuskan nilai-nilai mereka menjadi hukum umum sebagai teroris, otoritaris, ataupun imperialis, maka pihak yang tertindas yang memperjuangkan nilai-nilai pembebasan mereka juga dapat dituduh sebagai teroris (Nicholson,1990: 250).

Dengan kata lain, postmodernisme mengalami kontradiksi internal di dalam pendasaran epistemologisnya, terutama jika paradigma ini digunakan di dalam kerangka analisis feminisme (Putnam, 1987: 76). Kontradiksi internalnya begini, bukankah paradigma yang mau mengkritik metanarasi besar jugalah merupakan suatu metanarasi? Bukankah posisi postmodern yang antiepistemologi juga merupakan sebuah posisi epistemologis, walaupun jika posisi tersebut menolak pengadaian yang bersifat stabil? Jawaban dari kedua pertanyaan itu adalah "ya". Akan tetapi, para pemikir postmodern dapat mengelak dari tuduhan semacam ini dengan memasuki konsep ironi.

Kesadaran subyek postmodern adalah kesadaran yang bersifat ironis. Artinya, subyek memiliki keberjarakan dengan dunia maupun dengan dirinya sendiri. Ironi memungkinkan subyek untuk bersikap longgar terhadap kepercayaan maupun nilai-nilai yang dianutnya (Selski, 1995: 83). Subyek ironis", demikian tulis Richard Rorty, "ditandai dengan ketidakmampuan untuk menganggap diri sebagai sesuatu yang serius, karena selalu sadar bahwa semua nilai yang mereka anut akan berubah pada akhirnya, selalu sadar akan kontingensi dan kerapuhan dari kosa kata akhir mereka, dan terutama tentang diri mereka (Rorty, 1980: 65).

Dengan kalimat tersebut, Rorty mengajak kita untuk hidup di dalam tegangan, bahkan di dalam konflik antara nilai-nilai kehidupan yang kita anggap serius di satu sisi, dan sikap ironis kita yang selalu terbuka pada perubahan di sisi lain. "Ironi", demikian tulis 
Donna Haraway. "adalah tentang kontradiksi ... tentang tegangan berpegangan pada hal-hal yang tidak cocok sekaligus, karena keduanya adalah perlu dan benar.." (Nicholson, 1990: 190). Tesis tentang ironi memungkinkan postmodernisme keluar dari kontradiksi internal. Akan tetapi, isi dari tesis ironi tersebut juga dapat menjadi ironis, yang juga tidak harus dianggap serius. Tesis tentang ironi juga haruslah diperlakukan secara ironis, yakni sebagai salah satu bagian saja dari languange games atau lokalitas tertentu.

Walaupun kritik tentang kontradiksi internal dapat dihindari oleh postmodernisme, tetapi postmodernisme masih juga harus menjawab beberapa pertanyaan yang bersifat psikologis dari subyek ironis tersebut. Kita dapat mempertanyakan validitas refleksi dari hidup yang tidak dianggap serius oleh subyek ironis. Kita juga dapat mempertanyakan "kesehatan psikologis" dari orang-orang yang mengganggapi ironis prinsip-prinsip hidup dan nilai-nilai terdalam yang dianutnya. Kita tertantang untuk meragukan otentisitas hidup (belum menyebut gairah untuk hidup) dari kehidupan di mana pencapaian sejarah dari kesadaran diri diturunkan kualitasnya (Rorty, 1980: 75). Walaupun mendapat kritik dari berbagai dimensi, postmodernisme tetaplah merupakan sebuah refleksi filosofis yang kuat dan berpengaruh tentang "problematika otoritas dari rasionalitas". Postmodernisme merupakan sebuah tanggapan atas krisis rasionalitas, yang dihasilkan oleh proyek modernitas (Habermas, 1985: 7).

\section{Genealogi Postmodernisme}

Sejarah filsafat selalu bergerak dalam tegangan antara afirmasi ataupun negasi atas rasionalitas. Problem tersebut paling nyata di dalam pemikiran Immanuel Kant (Rorty, 1980: 80-85). Salah satu cara paling cepat untuk memperoleh gambaran menyeluruh tentang tegangan dan krisis rasionalitas itu adalah dengan menempuh empat langkah berikut.
Pertama, kita harus memahami pembedaan yang dibuat Kant antara rasionalitas yang tak terkondisikan, apriori, dan transendental pada satu sisi, dan kekuatan-kekuatan heteronom yang mempengaruhi rasionalitas dari luar di sisi lain. Kedua, kita juga harus memahami pengandaian bahwa rasionalitas tidaklah terkondisikan secara empiris. Ketiga, kita harus merefleksikan lebih jauh problem tersebut, dan menemukan bahwa rasionalitas transendental yang tak terkondisikan adalah tidak mungkin. Keempat, akhirnya, kita harus sampai pada kesimpulan bahwa ternyata rasionalitas hanyalah nama lain dari kekuasaan (power).

Perdebatan tentang krisis rasionalitas selalu berada setidaknya di dalam empat argumentasi tersebut. Saya akan berpendapat bahwa bahkan pembacaan kembali atas teksteks Immanuel Kant tetap akan membawa kita pada problematika atas rasionalitas yang belum terselesaikan. Di samping itu, berbeda dari postmodernisme, problematika tersebut bukanlah sesuatu yang tidak dapat dilampaui, melainkan bisa disintesakan tanpa jatuh pada penolakan atas rasionalitas, seperti yang banyak dilakukan para pemikir postmodern. Banyak filsuf berpendapat bahwa posisi postmodern tersebut meragukan secara filosofis. Pendapat tersebut cukup beralasan, karena postmodernisme menyalahpahami arti konsep rasionalitas, sehingga mereka berargumentasi atas kesalahpahaman akan konsep yang paling menjadi perdebatan di dalam sejarah filsafat, yakni atas konsep rasionalitas itu sendiri.

Kritik postmodernisme terhadap rasionalitas yang telah mengalami krisis dapat dipadatkan pada satu tesis, yakni kritik pada fondasionalisme. Fondasionalisme adalah paham yang berpendapat bahwa realitas dapat dijelaskan dengan menggunakan konsepkonsep dasariah, yang bisa dipahami secara logis dan rasional. Konsep-konsep tersebut bisa tunggal, bisa pula plural. Hal ini sangat 
penting, karena jika benar bahwa postmodernisme melandaskan kritiknya pada penolakan atas fondasionalisme, maka fondasionalisme tersebut, alih-alih dihancurkan, haruslah dirumuskan secara baru. Kant sendiri, menurut Jürgen Habermas, seorang penafsir Kant, juga mau merumuskan fondasionalisme tersebut secara baru. Kant menjadikan rasionalitas emansipatoris khas pencerahan sebagai cara untuk melampaui fondasionalisme Kuno khas filsafat Yunani Kuno, dan kemudian menggunakan rasionalitas tersebut di dalam praktek diskursif publik. Artinya, publik menggunakan rasionalitasnya secara kolektif di dalam dunia politik (Habermas, 1985: 152).

Rasionalitas disini dapat diartikan sebagai kebebasan, di mana rasionalitas digunakan di dalam aspek-aspek komunikatif pencapai konsensus dan kesalingpengertian, dan bukan untuk mencapai kemutlakkan. Dengan demikian, fondasionalisme dirumuskan secara baru, yakni dengan penggunaan rasionalitas secara publik untuk menciptakan keterbukaan dan mewujudkan kebebasan.

Penafsir Kant lainnya, Onnora O’Neil, mencoba melihat distingsi yang dibuat Kant tentang penggunaan rasionalitas secara publik, dan penggunaan rasionalitas secara privat. Penggunaan rasionalitas secara privat berarti rasionalitas digunakan secara terbatas pada yurisdiksi subyektif individu tertentu. Dalam konteks ini, rasionalitas tidak digunakan secara sempurna, terutama karena banyak sudut pandang dari rasionalitas individu lain, yang tidak tertampung, ataupun dilupakan. "Alasan Kant”, demikian tulis O’Neil, “untuk menekankan penggunaan rasionalitas secara publik adalah lebih baik digunakan secara publik daripada digunakan sendiri (penggunaan) rasionalitas secara privat dapat diartikan sebagai cacat...(O’Neil, 1992: 298).

Dalam hal ini, O'Neil, begitu juga Habermas, mengambil posisi tengah-tengah antara fondasionalisme di satu sisi dan relativisme di sisi lain di dalam membaca Kant. Berbeda dari kedua orang itu, relativisme, yang sering juga diidentikkan dengan postmodernisme, berpendapat bahwa rasionalitas adalah salah satu bentuk lain saja dari kekuasaan. Atau, di dalam kosa kata Foucault, rasionalitas adalah otoritas pendisplinan untuk melayani suatu "rezim kebenaran" (Foucault, 1980: 131). Habermas tidak setuju dengan pendapat semacam itu. Ia melihat rasionalitas sebagai elemen kontrol kekuasaan, dan bukan merupakan melulu bentukan lain dari kekuasaan, seperti yang diklaim oleh Foucault. Ia berpendapat bahwa masuk akallah bagi kita untuk merumuskan suatu situasi diskursif yang inklusif, bebas dominasi, dan egaliter dengan menggunakan rasionalitas untuk mencapai konsensus dan kesalingpemahaman, di mana kekuasaan dapat dinetralisir dengan kekuatan pemikiran kritis manusia. Meminjam inspirasi dari Habermas tersebut, maka kita bisa mengkritik tesis utama Foucault, yang melihat kekuasaan sebagai “....bukan posisi di luar relasi-relasi, seperti proses ekonomi, relasi pengetahuan, ataupun relasi seksual, tetapi imanen di dalamnya; kekuasaan adalah efek langsung dari ketidaksetaraan, pembagian kelas-kelas, yang muncul kemudian, dan kemudian merasuk secara internal di dalam kondisi-kondisi perbedaan tersebut; relasi kekuasaan bukanlah dalam arti suprastrutktural, melainkan memiliki peran produktif, dimanapun mereka ada (Foucault, 1981: 94).

Jika kekuasaan sungguh memiliki karakter produktif yang dapat membantu membentuk relasi-relasi diskursif, dan bukan merupakan kekuatan dari luar yang mungkin dapat memanipulasi, maka seluruh konsepsi diskursif yang dikembangkan Habermas melalui pembacaannya atas Kant tidaklah tepat. Satu hal yang pasti, kekuasaan adalah suatu bentuk relasi heteronom. Dan dengan begitu, konsepsi penggunaan rasionalitas 
secara publik di dalam filsafat politik Kant haruslah merupakan suatu bentuk situasi diskursus, di mana kekuasaan direlatifkan, jika tidak mau dikatakan absen, karena tidak mungkinlah situasi diskursif antara partisipan yang setara bisa berlangsung, jika kekuasaan menyebabkan kesenjangan sosial. Akan tetapi, dalam realitas, situasi diskursif ideal, di mana rasionalitas bisa sungguh-sungguh digunakan secara publik, tidaklah pernah terjadi, karena kekuasaan selalu menjadi bagian dari praktek rasionalitas tersebut. Yang terakhir inilah yang menjadi keyakinan Foucault, dan orang-orang yang menyetujui pendapatnya.

Tesis Foucault mengarahkan kita pada sikap pesimis atas rasionalitas, yang pada Kant, dan Habermas, justru menjadi tulang punggung refleksi. Pesimisme tersebut memang masuk akal, terutama jika kita berhadapan dengan idealisasi rasionalitas yang tampak agak berlebihan pada Kant dan Habermas. Konsepsi rasionalitas Kantian memang mengandaikan bahwa kekuasaan bersifat eksternal terhadap relasi-relasi diskursif. Dengan kata lain, idealitas rasionalitas Kantian dan Habermasian adalah eksklusi kekuasaan, dan menganggapnya sebagai pengaruh negatif dari "otoritas alien" dari relasi-relasi diskursif.

Di dalam pemikiran Foucault, kekuasaan tidak melulu dilihat sebagai entitas yang negatif, tetapi juga konstruktif dan produktif. Para pemikir yang menjadikan titik tolak rasionalitas ala Kant dan Habermas tentu saja akan kecewa dengan tesis Foucault tersebut. Foucault mengajak kita untuk menolak otoritas rasionalitas, karena pada hakekatnya, penggunaan rasionalitas tidak lain tidak bukan adalah pengunaan relasi-relasi kekuasaan juga, yang setara dan seimbang dengan unsur-unsur lainnya di dalam realitas. Penggunaan rasionalitas secara publik, dalam arti Foucault, juga merupakan penggunaan kekuasaan secara publik, sehingga tidak banyak perbedaaanya.
Menurut saya, idealitas Kantian dan Habermasian atas rasionalitas, lepas dari tesis kontroversial yang dirumuskan Foucault, tetaplah diperlukan. Yang dapat dilakukan adalah bukan menolak kekuasaan di dalam relasi-relasi diskursif, seperti diidealkan oleh Kant, melainkan mengikut sertakan kekuasaan tersebut di dalam relasi-relasi diskursif, tetapi dengan memberinya batas atau syarat, sehingga tidak menjadi dominan, dan merusak konsensus serta menciptakan kesalahpahaman.

Dengan memberi batasan atas relasirelasi kekuasaan yang negatif, rasionalitas juga mungkin mendorong relasi-relasi kekuasaan yang produktif dan konstruktif untuk beroperasi di dalam praksis. Itulah tujuan saya pada bab ini, yakni menawarkan rekonstruksi atas skeptisisme dan sinisme terhadap rasionalitas yang terjadi pada mayoritas pemikiran postmodernisme (Alcoff dan Elizabeth, 1993: 187-215).

Dengan catatan, rekonstruksi tersebut disandarkan pada konsepsi rasionalitas yang beroperasi untuk membatasi kekuasaan yang destruktif, sekaligus membuka ruang lebih lebar pada produktifitas dan kreativitas. Oleh sebab itu, seperti yang telah diidealkan oleh Kant dan Habermas, rasionalitas haruslah diidentikan dengan kebebasan. Nah, jika postmodernisme merumuskan rasionalitas sebagai bentuk kebebasan, maka tesis mereka yang mengganggap rasionalitas sebagai sebentuk teror, otoritarianisme, dan imperialisme, walaupun memiliki segi kebenarannya sendiri, dapat direkonstruksi secara lebih positif.

Sinisme dan apatisme postmodernisme terhadap rasionalitas, adalah sebentuk keputusasaan dan ekspresi dari ketidakmampuan (Rorty, 1980: 90. Sinisme tersebut tidak ditujukan langsung kepada rasionalitas itu sendiri, tetapi pada ketidakmampuan relasirelasi diskursif di dalam masyarakat untuk mewujudkan idealitas yang telah dirumuskan oleh Kant dan Habermas (Rorty, 1980: 115). 
Dengan kata lain, sinisme dan apatisme para pemikir postmodern terhadap rasionalitas lebih berakar pada ketidakmampuan mereka untuk mendistingsikan antara fungsi otoritatif rasionalitas, dan ekses otoritarianisme dari rasionalitas.

Distingsi antara fungsi otoritatif dan ekses otoritarianisme dari rasionalitas ini dapat digunakan untuk membantu kita "menyelamatkan" rasionalitas dari tikaman radikal postmodernisme. Hal inilah yang dilakukan oleh Thomas Nagel dalam bukunya The Last Word. Memang, di dalam buku tersebut, Nagel tidak pernah menggunakan kata postmodern, dan bukunya bukanlah merupakan suatu tanggapan terhadap postmodernisme. Akan tetapi, dampak subyektivis dan relativis yang merupakan ekses dari paradigma berpikir postmodernisme, menurutnya, haruslah dihentikkan. Seperti sudah disinggung sebelumnya, ia ingin "menyelamatkan" rasionalitas dari tikaman radikal subyektivisme dan relativisme, yang merupakan ekses langsung dari paradigma berpikir postmodernisme. Di samping itu, Nagel juga tidak setuju dengan konsekuensi politis yang dapat ditarik dari postmodernisme. Salah satu karakter politis dari postmodernisme adalah skeptisisme rasionalitas. Skeptisisme semacam itu bukanlah suatu tanggapan yang memadai terhadap metafisika ataupun filsafat, yang merefleksikan tempat rasionalitas di dalam kehidupan manusia, sehingga tidaklah bersifat ontologis, melainkan suatu gugatan terhadap otoritas rasionalitas di dalam relasi-relasi diskursif, sehingga lebih bersifat epistemologis dan praktis (Nagel, 1997: 6).

Tesis utama yang dikembangkannya di dalam buku itu adalah bahwa rasionalitas, lepas dari segala eksesnya, haruslah ditempatkan sebagai penentu "kata akhir" (Last Word). Dengan tesis tersebut, ia tidak bermaksud untuk kembali menarik minat para pemikir postmodern untuk merefleksikan kembali rasionalitas, sekaligus meninggalkan tendensi subyektivisme dan relativisme mereka. "Saya", demikian tulis Nagel, " tidak pernah secara serius berharap bahwa setiap karya yang membuktikan bahwa rasionalitas itu mungkin akan menjadikan relativisme tidak lagi menarik (Nagel, 1997: 13).

Dari semua uraian yang telah saya rumuskan di atas, kita setidaknya dapat merangkum dua butir refleksi. Pertama, solusisolusi yang bersifat ironis (Rorty), mengagungkan lokalitas (Lyotard), ataupun nomadisme sama sekali tidak dapat menyelesaikan problem ekses-ekses dari relasirelasi diskursif, yakni terorisme rasionalitas. Solusi-solusi yang ditawarkan para pemikir postmodern tidak dapat memberikan sumbangan apapun terhadap problematika ini. Jika para partisipasi diskursif yang berpikir secara rasional dan argumentatif dan berinteraksi di dalam lingkaran teror dan kekuasaan yang destruktif, maka solusi yang bersifat ironis dan nomadis hanya akan bersikap secara sinis di dalam menanggapi argumentasi tersebut. Sikap tersebut tidak dapat memberikan kontribusi apa-apa, kecuali fatalisme, dan itu berarti berpindah dari teror yang satu menuju teror yang lain.

Kedua, problematika krisis rasionalitas yang diangkat menjadi salah satu tema refleksi utama para pemikir postmodern hanyalah ketidakmampuan membedakan antara rasionalitas yang bersifat otoritatif di satu sisi, dan rasionalitas yang bersifat otoritarianisme di sisi lain. Nah, jika kita mampu memahami rasionalitas sebagai elemen otoritatif, seperti dipahami oleh Habermas dengan rasionalitas komunikatifnya, maka pertanyaan epistemologis tentang krisis rasionalitas seharusnya tidak lagi merupakan masalah. Dan jika landasan epistemologisnya sudah jelas, maka elemen praktis dan penerapan etisnya juga tidak lagi menjadi masalah.

Apa yang menjadi fokus utama para filsuf feminis tentang epistemologi adalah 
problematika otoritarianisme diskursif. Problematika otoritarianisme diskursif ini adalah "kondisi", demikian tulis Fricker, "dari kodrat kita untuk menyatakan bahwa konsepsi kita tentang otoritarianisme rasionalitas mengijinkan perbedaan kontras dengan berbagai perilaku diskursif lainnya yang kita anggap sebagai non-otorianisme (Rorty, 1980: 157). Sikap ironis dan sinis terhadap relasirelasi diskursif dan rasionalitas yang terkandung di dalamnya tidak akan membuahkan apapun. Kita harus secara jeli membedakan antara rasionalitas yang terletak di dalam bahasa, dan yang kemudian digunakan untuk mewujudkan relasi-relasi diskursif pencapaian kesaling pemahaman di satu sisi, serta rasionalitas yang bersifat otoritarianisme, fondasional, metanaratif, yang kerap kali berpihak pada konservatisme.

Refleksi dan analisis yang menyangkut otoritas rasionalitas selalu berkaitan dengan pertanyaan tentang kebebasan di satu sisi, dan pertanyaan tentang kehendak bebas di sisi lain, karena struktur analisis dan refleksi dari kedua pertanyaan tersebut memiliki struktur yang mirip. Kebebasan selalu berada dalam oposisi dengan otoritarianisme. Sementara, refleksi tentang kehendak bebas selalu berada oposisi dengan determinisme. Determinisme, yang mengandaikan adanya sebab akibat, tidaklah sahih ipso facto. Ia tidak mengakui adanya kausalitas, melainkan "pembatasan dan ketidakleluasaan" (constraint). Pada titik ini, rasionalitas tidaklah kita tempatkan sebagai kekuasaan sosial yang bersifat otoriter, yang dalam arti tertentu mendeterminisasi hampir semuanya dan mendikte kebebasan maupun kehendak manusia, melainkan sebagai pembatas dari operasionalisasi kekuasaan itu sendiri, yakni sebagai kontrol dan pembatas dari kekuasaan yang bersifat otoriter (Quine, 1969: 69-90).

Jika kita bisa mengubah refleksi kita atas rasionalitas dari cara memahaminya sebagai otoriter dan konservatif, dan kemudian memahaminya dalam kerangka etis, yakni sebagai pembatas dan kontrol atas kekuasaan, maka kita bisa menjadi apa yang disebut Fricker sebagai orang yang"berpikir tentang permukaan secara mendalam (Rorty, 1980: 165). Artinya, kita mampu melihat distingsi permukaan atas pemahaman tentang rasionalitas, yakni sisi otoriternya dan sisi otoritatifnya. Pemahaman atas permukaan juga membantu kita merubah pemahaman atas dimensi ontologis dari rasionalitas itu sendiri. Memang, pembedaan seperti ini tidaklah terlalu terlihat di dalam praktek kehidupan sehari-hari. Akan tetapi, pembedaan di dalam memahami rasionalitas itu tetaplah sesuatu yang perlu. Feminisme, di dalam perkembangannya, lebih membutuhkan dan mengandaikan adanya rasionalitas yang bersifat otoritatif di dalam relasi-relasi diskursif, dengan tidak mengabaikan serta tetap kritis terhadap praktek-praktek otoriter dari rasionalitas. Pemahaman filosofis yang benar atas problematika rasionalitas masihlah sangat penting untuk kita. Pemahaman yang benar tersebut akan mendorong praksis yang juga tepat, sehingga kita dapat lebih peka dan kritis di dalam membuat penilaian-penilaian, baik itu etis maupun strategis, di dalam relasirelasi diskursif praktis.

Praktek yang tepat selalu sudah mengandaikan pemahaman epistemologis yang tepat. Distingsi epistemologis antara rasionalitas otoriter dan rasionalitas otoritatif juga akan membantu kita menentukan praksis yang tepat. Sebaliknya, praksis yang tepat atas penggunaan rasionalitas yang otoritatif tersebut juga akan membawa implikasi positif bagi refleksi kita tentang problematika krisis rasionalitas, yakni kemampuan memandang secara tepat berdasarkan praksis yang tepat. Dengan demikian, pengandaian epistemologis yang tepat akan membantu kita bertindak juga secara tepat, dan sebaliknya, praksis yang tepat, pada akhirnya, akan membantu kita merefleksikan problematika epistemologis 
secara tepat (Code, 1995: 58-82). Sinisme dan skeptisisme para pemikir postmodern, jika dihadapkan pada tesis ini, akan tampak tidak menawarkan apa-apa.

Harus diakui, paparan yang saya berikan diatas memang terkesan tidak adil. Di dalam tesis para pemikir postmodern tentang terorisme rasionalitas, dan di dalam perjuangan para feminis postmodern akan inklusifitas, kita akan menemukan suatu keprihatinan yang mendalam. Di dalam konteks epistemologi, para pemikir postmodern, termasuk para pemikir feminisnya, mau memberikan ruang yang lebih besar bagi pluralisme epistemologis. Pluralisme semacam ini adalah bagian dari perjuangan kebebasan, yang seringkali di dalam epistemologi tradisional ditekan atas nama rasionalitas ataupun narasi besar lainnya. Pembelaan radikal postmodernisme pada pluralitas terhadap tendensi totalitas dan unifikasi tentu merupakan suatu hal yang sangat menarik bagi para pemikir feminis. Pembelaan ini pulalah yang menjadikan postmodernisme, pada hakekatnya, merupakan sekutu yang tangguh bagi perjuangan feminisme. Akan tetapi, persekutuan ini, seperti sudah saya tunjukkan sebelumnya, justru bisa menjadi ilusi yang menghalangi perjuangan feminisme, karena rasionalitas ditanggapi dengan sangat sinis dan skeptis, sehingga tolok ukur kriteria perjuangan pada akhirnya juga menjadi relatif, jika tidak mau dikatakan hilang.

Kelemahan pertama tesis-tesis postmodernisme adalah sikap sinis mereka terhadap otoritas rasionalitas. Mereka menganggap rasionalitas sebagai sebentuk ilusi. Pada hemat saya, perjuangan feminisme tidaklah membutuhkan kritik atas rasionalitas yang radikal, karena pada akhirnya kritik tersebut akan menghancurkan nilai perjuangannya dengan membawa feminisme pada relativisme, melainkan pembedaan epistemologis di dalam memandang dimensi otoriter dan dimensi otoritatifnya. Rasionalitas otoritatif ini searah dengan tesis Jürgen Habermas tentang rasionalitas komunikatif, yakni rasionalitas yang bekerja di tataran relasirelasi diskursif, di mana setiap partisipan diskursus mampu melakukan tindak komunikatif di bawah rambu-rambu situasi perbincangan ideal, dan mampu melampaui perspektifnya sendiri serta menggunakan perspektif lawan bicaranya. Memang, kita sudah melihat bagaimana secara sekilas, tesistesis postmodernisme, dengan pembelaan radikalnya atas perbedaan dan atas 'yang lain', mampu menarik perhatian para pemikir feminis. Akan tetapi, kita juga sudah melihat bahwa pembelaan radikal atas perbedaan, seperti yang diajukan oleh para pemikir postmodern, juga pada akhirnya akan membawa perjuangan dan refleksi feminisme pada arah yang salah.

\section{Pluralisme Rasionalitas}

Setelah membedakan antara rasionalitas yang bersifat otoritatif dan yang bersifat otoriter, kita masuk mendefinisikan sejauh mana pluralisme di dalam rasionalitas yang bersifat otoritatif itu perlu. Pluralisme selalu mengandaikan adanya perbedaan di dalam cara memandang atas dunia yang satu, yakni dunia yang kita hidupi bersama. Dunia yang kita hidupi bersama ini haruslah kita andaikan dahulu. Dunia semacam ini mengimplikasikan adanya pihak-pihak yang memiliki nilai-nilai etis maupun politis yang berbeda, walaupun mereka hidup di dalam dunia yang sama. Relasi antara pihak-pihak yang menghidupi dunia yang sama itu jugalah merupakan sebuah relasi yang didasarkan pada kerangka etis dan nilai-nilai tertentu. Semua relasi dialektis antara masing-masing pihak yang hidup di dalam dunia yang dipandang secara berbeda tersebut haruslah dibiarkan terbuka dan bermain membentuk suatu wacana-wacana otoritatif, di mana kriteria dan tolok ukur normatif 
digantungkan. Kriteria normatif tersebut bukanlah sesuatu yang sudah jadi, melainkan terus berproses. Dalam dunia yang dihidupi bersama tersebut, rasionalitas haruslah ditempatkan pada posisi otoritas normatif, yang mampu menjadi tolok ukur ideal segala tindakan sosial. Secara ontologis, rasionalitas adalah otoritatif. Akan tetapi, secara praktis, rasionalitas haruslah diimplementasikan secara plural dan kontekstual. Pluralisme yang kita butuhkan adalah pluralisme di dalam tindakan (Code, 1995: 58-82).

Para pemikir postmodern mau mewujudkan pluralisme epistemologis di seluruh level pengetahuan maupun tindakan manusia sebagai tindak perlawanan mereka terhadap otoritarianisme epistemologis. Mereka melakukan proses pluralisasi di seluruh dimensi epistemologis manusia, dan tidak memfokuskan pada praksis dari refleksi epistemologis tersebut. Bagi mereka, pluralisme adalah suatu tesis ontologis tentang realitas yang terpecah-pecah. Metafisika tentang kebenaran yang beragam. Suatu refleksi epistemologis tentang parsialitas dari perspektif manusia (Quine, 1969: 110). Sementara mereka keasyikan berteriak tentang perbedaan, refleksi atas praksis yang membutuhkan acuan normatif yang otoritatif dan kontekstual justru tampak terabaikan.

Pluralisme disini haruslah juga membuka peluang pada aspek perbedaan status sosial dan ekonomi, yang memiliki dampak langsung pada cara memandang dunia seseorang, dan juga pada kekuasaan yang akan mempengaruhi proses penentuan pandangan siapa yang lebih rasional daripada yang lainnya. Pada titik ini, pluralisme yang menjadi tesis utama adalah semacam sintesa antara rasionalitas di dalam relasi-relasi diskursif yang telah dirumuskan Kant dan Habermas di satu sisi, dari pluralitas epistemologis rasionalitas yang dirumuskan para pemikir postmodern di sisi lain. Rasionalitas diskursif, seperti yang dirumuskan Habermas, haruslah juga peka pada kekuasaan, yang telah bersifat imanen di dalam relasirelasi diskursif tersebut. Dan pluralitas epistemologis, seperti yang dirumuskan oleh para pemikir postmodern, tidaklah jatuh pada relativisme epistemologis dan praksis, tetapi untuk menjamin bahwa praktek diskursus kritis tetaplah berjalan dan tidak menjadi mutlak (Habermas, 1992: 145).

Realitas sosial selalu dapat dikonsepsikan sebagai ontologi tunggal, yang dapat diteropong dari berbagai positif, dan kesemuanya cara meneropong tersebut dapat disebut sebagai rasional. Ini adalah tesis pokok dari realisme perspektival. Penentuan siapa yang paling rasional di antara berbagai pandangan yang juga rasional tersebut ditempuh melalui proses diskursif. Tesis ini memperoleh penyempurnaannya dari pemikiran Foucault, yang melihat setiap relasi diskursif sudah selalu menyembunyikan kekuasaan yang imanen di dalamnya. Dengan demikian, apa yang tampaknya sedemikian rasional pada awal mulanya, kini menjadi tidak terlalu rasional lagi, karena dipengaruhi oleh relasi-relasi kekuasaan yang dominan di dalam jaringan-jaringan diskursif. Akan tetapi, perspektif Foucault, pada akhirnya, juga menjadi relatif, terutama karena pengetahuannya tentang relasi-relasi kekuasaan juga dijalari oleh relasi-relasi kekuasaan. Foucault lupa bahwa kekuasan juga selalu dapat dibatasi dan dikontrol, jika penggunaan rasionalitas secara publik, seperti yang dikonsepsikan oleh Habermas dan Kant, dapat dilakukan secara konsisten.

\section{Penutup}

Dalam melihat rasionalitas dengan membedakan antara segi otoriternya di satu sisi, dan segi otoritatifnya di sisi lain kita harus jeli melihat pembedaan tersebut. Distingsi ini bisa ditemukan hampir di seluruh konsepsi penilaian manusia akan sesuatu. Distingsi ini memang sekilas hanya tampak sebagai distingsi vokabuler, dan tipis perbedaannya. Akan 
tetapi, solusi dan akar masalah terkadang hanya berbeda setipis benang, dan yang dibutuhkan hanyalah sedikit kejelian untuk melihat benang tersebut. Misalnya, penilaian bahwa ia adalah orang yang bermoral, tetapi tidak moralistik. Ia adalah orang yang penuh dengan perasaan, tetapi tidak sentimental (full of sentiment but not sentimental). Rasionalitas, lepas dari semua bentuk krisis dan kontradiksi di dalamnya, haruslah diupayakan terus menerus menjadi sebentuk otoritas, di mana kebebasan di dalam relasi-relasi diskursif menemukan aktualitasnya. Akan tetapi, kriteria-kriteria penggunaan rasionalitas secara publik haruslah terus terbuka untuk revisi dan klarifikasi, sehingga ia tidak menjadi entitas yang otoriter.

Rasionalitas, sebagai sebentuk otoritas, haruslah diterapkan pada praksis. Postmodernisme tidak menjadikan rasionalitas sebagai kata akhir. Mereka merefleksikan kekuasaan di balik semua aspek kehidupan manusia, dan berhenti di situ. Apa yang membuat pertanyaan tentang otoritas rasionalitas penting untuk refleksi epistemologis, rasionalitas haruslah berhenti pada praksis, dan praksis selalu membutuhkan kerangka rasional yang otoritatif. Kerangka rasionalitas yang memiliki otoritas inilah yang dibutuhkan oleh perjuangan dan refleksi feminisme.

\section{Daftar Pustaka}

Hillary Putnam, "Why Reason Can't Be Naturalized?" dalam Kenneth Baynes, Thomas McCarthy, dan James Bohman (ed), End Of Philosophy: End or Transformation?, Cambridge, MIT Press, 1987.

Jean-Francois Lyotard, The Postmodern Condition. A Report on Knowledge, Manchester, Manchester University Press, 1984.

Jürgen Habermas, Postmetaphysical Thinking. Philosophical Essays, Cambridge, MIT Press, 1992.
Jürgen Habermas, The Philosophical Discourse of Modernity, Cambridge, Polity Press, 1985, Linda Alcoff dan Elizabeth Potters (ed), Feminist Epistemologies, London, Routledge, 1993.

Linda J. Nicholson, Feminism/Postmodernism, London, Routledge, 1990.

Lorraine Code, Rhetorical Spaces: Essay on Gendered Locations, London, Routledge, 1995.

M. Foucault, Power/Knowledge: Selected Interviews \& Other Writings, 1972-1977, London, Harvester, 1980.

M. Foucault, The History of Sexuality vol. 1: An Introduction, London, Pelican Books, 1981.

Onora O’Neil, 'Vindicating Reason', dalam Paul Guyer (ed), The Cambridge Companion to Kant, Cambridge, Cambridge University Press, 1992,

Richard Rorty, Contingency, Irony, and Solidarity, Cambridge, Cambridge University Press, 1989.

Richard Rorty, Philosophy and The Mirror of Nature, Oxford, Blackwell, 1980.

Rita Selski, The Gender of Modernity, Cambridge, Harvard University Press, 1995.

Robert Wardy, The Birth of Rhetoric: Gorgias, Plato, and Their Succesors, London, Routledge, 1996.

Sabina Lovibond, "Feminism and Postmodernism”, New Left Review 178, 1989.

Sabina Lovibond, "The End of Morality", dalam Kathleen Lennon dan Margaret Whitford (ed), Knowing the Difference: Feminist Perspective in Epistemology, London, Routledge, 1994.

Seyla Benhabib, Feminist Conditions: A Philosophical Exchange, London, Routledge, 1995.

Thomas Nagel, The Last Word, Oxford, Oxford University Press, 1997.

W.V.O. Quine, Ontological Relativity and Other Essays, New York, Columbia Press, 1969. 